\title{
EXPLORING ENGLISH STUDENT TEACHERS' READING HABITS AND PREFERENCES
}

\author{
Muhsiyana Nurul Aisyiyah \\ IAIN Syekh Nurjati Cirebon \\ muhsiyana@gmail.com \\ Mohammad Andi Hakim \\ IAIN Syekh Nurjati Cirebon \\ andihakim@syekhnurjati.ac.id
}

\begin{abstract}
The vast benefits of reading in both the first and the target language makes reading essential for English Language Teaching Department students who are not only English language learners but also English teacher candidates. This study explores English student teachers' reading habits and preferences. An open-ended and closed-ended questionnaire and interviews were used to collect information on 88 English student teachers' reading habits and preferences. The participants' reading habits were predicted by their attitudes towards reading, reading frequency, and reading material preferences. The findings suggest that although student teachers mostly displayed positive attitudes towards reading and acknowledged the importance of reading, they didn't really invest in personal reading. In terms of reading preferences, most of the student teachers chose fiction books and online materials as the most preferred reading materials. When it comes to language preferences, most of them preferred to read in their first language (Indonesian) instead of the language they are currently learning (English) for both academic reading and reading for pleasure.
\end{abstract}

Keywords: reading, reading habits, reading preferences, attitudes towards reading, English student teachers

\section{BACKGROUND}

In Indonesian context, English student teachers are mostly, if not all, English teacher candidates whose first language is not English. After graduating from universities, they will likely experience a shift from being English language learners to English teachers. These teacher candidates face challenges such as the pressure to be highly proficient in English language because it is expected of them to demonstrate English language skills as good as possible to their students (Snow, 2007). Therefore, it is important for the English student teachers to make the most of their time to develop their English proficiency. One of the best ways to acquire L2 and foreign language proficiency, aside from living amidst the native speakers, is to read extensively in the learned language (Nuttal, 1996). Therefore, reading is considered essential for language learners. 
The next reason why reading is crucial for student teachers is that their future duties shall include being the reading role models for their students. Serving as the role models requires them to demonstrate their reading preferences, enjoyment, and passions which will likely influence on how their future students respond to reading (McKool \& Gespass, 2009). For this reason as well as for the language proficiency reason, we were interested in observing English student teachers' reading habits and preferences.

\section{Reading in the First and Foreign Language Context}

Regarding reading's role in the first language acquisition, reading promotes metalinguistic awareness and boosts vocabulary growth, grammar performance, writing and speaking skills in one's first language (Anderson \& Nagy, 1993; Cunningham, 2005; Krashen, 2011).

In second language acquisition and EFL learning contexts, reading activities expose language learners to a variety of words and sentence structures in the target language. This kind of exposure is important for learners' language development. One of the most renowned proponents of this view is Krashen with his 'input hypothesis' that has gained widespread acceptance in L2 context (Gardner, 2004). Input hypothesis believes that L2 acquisition occurs when a learner receives the learned language input that is above his/her level of language skills and this kind of input is called 'comprehensible input' (Krashen, 2009). Reading, especially extensive reading, is believed to be one of powerful sources of comprehensible input.

Learners who read extensively are also benefitted in terms of writing proficiency (Hafiz \& Tudor 1989; Lee \& Krashen, 1997; and Renandya \& Jacobs, 2002). This is due to the large quantity of language chunks the learners encounter as they read a lot. By reading a lot learners are exposed to a large amount of words, various sentence structures, writing styles, ideas, and writing organization that are better than their own. It is common knowledge that people who read more produce better writing (Lee \& Krashen, 1997).

Reading is also an activity that has been linked to learning autonomy (Ríos \& Valcárcel, 2005; Imrie, 2007; Channuan \& Wasanasomsithi, 2012; Teng, 2018; and Takahashi \& Umino, 2020) probably due to its private or individual nature. Each learner can decide what to read, where to read, when to start reading, and when to stop it. Learning autonomy is considered important for foreign language learners. Autonomous language learners are always motivated to learn and improve their language skills. They also strive to create more opportunities to communicate using English even though their surrounding environment is populated with nonnative English speakers. This kind of learners lead more effective and fruitful learning than learners that depend solely on instructions from their language teachers.

The vast benefits of reading in both the first and the target language for learners' language development make reading a necessity for English Language Teaching Department students as language learners. 


\section{Teachers as Readers}

Before entering the school ground, children reading habits are developed by their families' literacy practices; and parents play an important role during this phase. After enrolling in schools, teachers are considered as the capable adults who have great influences on children's or students' reading habits (McKool \& Gespass, 2009). The question is how do teachers influence their students? Do teachers greatly influence their students merely by what they say or do students learn more by observing what their teachers do? Research suggests that in addition to curriculum, teachers' behavior and values greatly influence their students' minds and hearts (Nathanson, Pruslow, \& Levitt, 2008). This is also the case with developing students' reading habits. As reading role models for their students, teachers not only need to convey their love for reading in words, but they need to demonstrate their own reading habits and their passion for readings. Teachers need to show their students through behavior in order for that demonstration to be effective (McKool \& Gespass, 2009). It is reported that teachers with good reading habits employed more reading instructions such as reading aloud, accompanying their students in libraries, recommending books, allocating independent reading time for students, and joining book discussions, all of which are useful to engage students in reading activities (Morrison, Jacobs, and Swinyard, 1998). It is evident that teachers' beliefs in reading as well as their own personal readings can influence their students. It is evident that teachers' beliefs in reading as well as their own personal readings can influence their students' reading habits.

\section{Reading habits and Preferences}

Indeed, reading is pivotal for English Language Teaching Department students who are not only English language learners but also English teacher candidates. However, not every student has keen interests in reading. This depends on individual preferences. Factors such as culture, gender, profession, and individual's interest affect reading habits and preferences (Ögeyik \& Akyay, 2009). Several notions regarding reading habits have been proposed. The first notion comes from Sangkaeo (1990) who regards reading habits as 'the behavior which expresses the likeness of reading of individual types of reading and tastes of reading'. Meanwhile, Wagner (2002) refers reading habits to the quantity of reading materials, reading frequency, and the time spent to read (Wagner, 2002). This is quite similar to Shen's (2006) idea about reading habits which are related to what one reads, how often, and how much he/she does it. Meanwhile, reading preferences indicate what someone might read if he or she is given the chance (Spangler, 1983).

Considerable research has been done to examine reading habits and preferences in various contexts. Applegate et al. (2014) conducted research on reading habits of college students aspiring to be teachers in American context. They found that $48.9 \%$ of those who aspire to be teachers do not possess a love of reading. Meanwhile, Nathanson, Pruslow, and Levitt (2008) found out 'a high prevalence of aliteracy' (having the ability to read but choosing not to do personal readings) among the in service teachers and pre service teachers enrolled in a graduate school 
of education in America. Research on pre service teachers were also conducted in other countries such as the South African student teachers' reading habits (Rimensberger, 2014) and student teachers' reading habits and preferences in Turkey (Ögeyik \& Akyay, 2009). However, few has been conducted in Indonesian context. Among the few is the research on the reading habits of student teachers enrolled in a graduate school in Malang (Priajana, 2013). All of these studies suggest that a good reading habit is necessary for pre service teachers or student teachers.

The present study focuses on examining the reading habits and preferences of English Language Teaching Department students and we also try to see whether the current digital technology advancements have any effects on what the students read. This study attempted to answer the following questions: 1) How are the English student teachers' reading habits which are predicted by their reading frequency, attitude towards reading, and reading materials preferences? 2) Do students generally prefer to read in online format? and 3) What language do they prefer their reading materials written in?

\section{METHOD}

This is survey research focusing on collecting information on English student teachers' reading habits and preferences. The research was conducted in 2020 with 88 student teachers voluntary participated. The participants were the fourth year students of English Language Teaching Department in a state higher education institution in West Java, Indonesia. When this study was conducted, the participants were teaching English at junior or senior high schools under the supervision of certified teachers to obtain a degree in education. The participants were chosen with the random sampling technique.

Table 1. Participants' Demographic Information

\begin{tabular}{|l|l|}
\hline Gender & \\
\hline Male & 13 participants \\
\hline Female & 75 participants \\
\hline Age Range & \\
\hline 19 years old & 8 participants \\
\hline 20 years old & 46 participants \\
\hline 21 years old & 24 participants \\
\hline 22 years old & 6 participants \\
\hline 23 years old & 4 participants \\
\hline
\end{tabular}

There was only a small number of male students in this department, hence, gender differences in reading habits and preferences were not closely examined. A questionnaire consisted of close ended sections and open ended sections were distributed to the participants. Semi structured interviews were also conducted to find out more about their reading habits and preferences. The collected data from the questionnaire were then analyzed using simple descriptive statistics such as percentages, frequency count, and ranking. Subsequently, the interviews were transcribed. The results of both the simple descriptive statistics and the interviews' 
transcripts were then closely examined to identify the recurring theme and pattern of student teachers' reading habits and preferences.

\section{FINDINGS AND DISCUSSION}

The theoretical framework used in this study defines reading habits as behavior which expresses the likeness towards reading (Sangkaeo, 1990), time spent on reading, and reading materials (Wagner, 2002, and Shen, 2006). Therefore, to describe the participants' reading habits and preferences, we provide information on those three aspects, i.e. reading behavior/attitude, reading frequency, and reading material preferences. In addition, we also provide further information on participants' reading format preferences to see whether they prefer online format to the more traditional format such as the print format. We consider this information important and intriguing because we are living amidst the digital technology advancements. Lastly, we also take a look at the participants' language preferences when reading either for informational/ academic purposes or for recreational purposes.

\section{Reading Frequency}

The English student teachers' reading frequency is presented in Table 2. The reading frequency reported by the participants refers to how often they read per day for both academic purposes (independent study) and recreational purposes (their personal interests).

Table 2. Reading Frequency

\begin{tabular}{|l|l|l|l|}
\hline No. & Reading Time per Day & Percentage & Participants' Number \\
\hline 1 & Less than 1 hour & $47.7 \%$ & 42 \\
\hline 2 & About 1 hour & $43.2 \%$ & 38 \\
\hline 3 & About 2 hours & $6.8 \%$ & 6 \\
\hline 4 & More than 2 hours & $2.3 \%$ & 2 \\
\hline
\end{tabular}

How often and how much one reads are possibly the most obvious indicators of someone's reading habits. The data in Table 2 shows that almost half of the participants $(47.7 \%)$ stated that they normally read less than one hour per day. This number is striking compared to the student teachers with high reading frequency (6.8\% of the students read 2 hours per day and $2.3 \%$ of the students read more than 2 hours per day). This finding suggests that most of the student teachers do not spend much time to read even for their academic purposes. The low reading frequency might also indicate low reading motivation as reading frequency is generally has positive correlation with reading motivation (Wingfield \& Guthrie, 1997; Guthrie et al., 1999; and Cox \& Guthrie, 2001). This is rather unfortunate because reading extensively has many benefits for them as students.

Even more discouraging is the fact that they are teacher candidates. After obtaining a degree in education, they will likely be teachers whose duties shall include promoting reading and developing students into enthusiastic readers who they themselves are not. This can turn into a vicious cycle in which unenthusiastic 
readers become teachers and then they struggle to inspire their students to read, which results in producing unenthusiastic readers as well (Applegate et al., 2014). To break this cycle, teachers are encouraged to read starting from their training years. 'A teacher who reads and a reader who teaches' (Commeyras, Bisplinghoff, \& Olson, 2003) would be the ideal role model for their students to habituate a love of reading. Teachers who read would likely position themselves as 'fellow readers'. They will share their reading excitement as well as experiences, then they will invite the students to share their own reading experiences. This is considered as the most ideal way to develop our students as readers because pleasure for and love of reading cannot be taught; they can only be shared.

\section{Student Teacher's Attitude towards Reading}

The second indicator of reading habits is general attitudes towards reading. The information on student teachers' general attitude towards reading is displayed in Table 3.

Table 3. Attitude towards Reading

\begin{tabular}{|l|l|l|l|l|l|}
\hline \multirow{2}{*}{ No. Item } & \multicolumn{1}{|c|}{ Yes } & \multicolumn{2}{c|}{ No } \\
\cline { 3 - 6 } & & F & \% & F & $\%$ \\
\hline 1 & Do consider yourself a good reader? & 50 & 56.8 & 38 & 43.2 \\
\hline 2 & $\begin{array}{l}\text { Do you think reading is essential for your } \\
\text { life? }\end{array}$ & 75 & 85.2 & 13 & 14.8 \\
\hline 3 & Do you like reading in your leisure time? & 58 & 65.9 & 30 & 34.1 \\
\hline 4 & $\begin{array}{l}\text { Do you prefer reading a book or watching } \\
\text { a movie in your leisure time? }\end{array}$ & 16 & 18.2 & 72 & 81.8 \\
\hline 5 & Do you read voluntarily and extensively? & 38 & 43.2 & 50 & 56.8 \\
\hline 6 & $\begin{array}{l}\text { Do you read only the books } \\
\text { recommended by your lecturers? }\end{array}$ & 47 & 53.4 & 41 & 46.6 \\
\hline 7 & $\begin{array}{l}\text { Do you usually find the book you want to } \\
\text { read in the library? }\end{array}$ & 34 & 38.6 & 54 & 61.4 \\
\hline 8 & $\begin{array}{l}\text { Do you usually buy the book you will } \\
\text { read? }\end{array}$ & 48 & 54.5 & 40 & 45.5 \\
\hline 9 & $\begin{array}{l}\text { Do you usually discuss the books you've } \\
\text { read with your friends? }\end{array}$ & 46 & 53.3 & 42 & 47.7 \\
\hline 10 & Do you belong to a book club? & 8 & 9.1 & 80 & 90.9 \\
\hline
\end{tabular}

Table 3 shows that most of the student teachers $(56.8 \%)$ perceived themselves as a good reader and considered reading essential for their lives $(85.2 \%)$. It is also reported that they enjoyed reading in their leisure time (65.9\%). This is somewhat in contrast with the responses to the next questionnaire items. Around $81.8 \%$ of the participants said that they preferred watching movies to reading a book during leisure time and only 38 participants $(43.2 \%)$ said that they read extensively. Half of the participants $(53.4 \%)$ stated that mostly they only read the books recommended by their lecturers.

In terms of library roles, less than half of the participants (38.6\%) went to libraries to look for the books they want to read. Around $54.5 \%$ of them prefer to 
buy the books they are going to read from offline bookstores or online bookstores. The participants also engaged in post reading activities $(53.3 \%)$ such as discussing the book they read with their friends. However, only a small number of students $(9.1 \%)$ joined a book club. The finding in this section reveals where improvements need to be made, i.e. campus library, reading areas, and reading community development. Supports from the university's policy makers are needed. To sum up the finding in in this section, out of 10 indicators of self reported reading attitudes, 6 indicators received positive responses from more than half of the students.

\section{Reading Material Preferences}

The information on the reading materials preferred by the student teachers is presented in Table 3.

Table 3. Reading Material Preferences

\begin{tabular}{|l|l|l|l|l|l|}
\hline No. & \multicolumn{1}{|c|}{ Item } & \multicolumn{1}{|c|}{ Yes } & \multicolumn{2}{c|}{ No } \\
\cline { 3 - 6 } & & F & \% & F & \% \\
\hline 1 & $\begin{array}{l}\text { Do you like reading textbooks for your } \\
\text { courses? }\end{array}$ & 68 & 77.3 & 20 & 22.7 \\
\hline 2 & $\begin{array}{l}\text { Do you like reading journals or research } \\
\text { reports? }\end{array}$ & 54 & 61.4 & 34 & 38.6 \\
\hline 3 & Do you like reading newspapers? & 57 & 64.7 & 31 & 35.3 \\
\hline 4 & Do you like reading fiction? & 70 & 79.5 & 18 & 20.5 \\
\hline 5 & $\begin{array}{l}\text { Do you generally prefer fiction or non } \\
\text { fiction genres? }\end{array}$ & 65 & 73.9 & 23 & 26.1 \\
\hline
\end{tabular}

Reading habits can also be predicted by reading materials. The information on what the students read consists of reading materials for academic purposes and reading materials for their personal interests. More than half of the student teachers $(77.3 \%)$ responded positively to reading textbooks for their courses and as many as $61.4 \%$ of them stated that they like reading research reports. Around $64.7 \%$ of the participants stated that they like to read newspapers. When they were asked further, they read newspapers because they wanted to know the latest happenings in Indonesia and in the world. The same trend also occurred in students' preferences towards reading fictions. It is reported that 65 participants $(73.9 \%)$ prefer fiction to non fiction genre.

The participants were then asked to rank the reading materials they most preferred. The result is displayed in Figure 1. Fiction books are the reading materials the participants preferred the most (32 participants). The second most preferred reading material is online materials (27 participants) which encompasses online information, blogs, movie reviews, travel reviews, food reviews, and other information. It is followed by course textbooks (11 participants), offline newspapers (14 participants), and journals or research reports (4 students). 


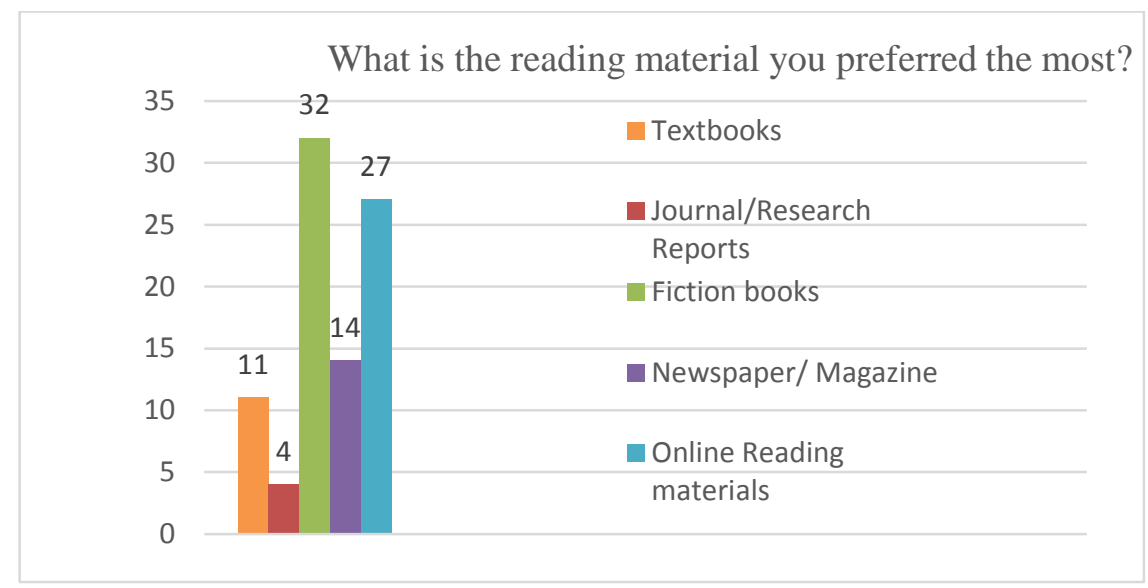

Figure 1. Genre Preferences

This finding shows that most of the participants choose fiction books as their most preferred reading material. One of the probable reasons for this findings is the large number of female participants (75 people) compared to that of male participants (13 people). It has been known that women display a strong preference for fiction and the number of men who prefer to read non fiction is twice the number of women who loves to read non fiction (Summers, 2013). Displaying a strong preference for fiction books has its own benefits. It was reported that reading fiction books positively impacts reading related skills such as reading comprehension, vocabulary, word reading, and oral comprehension (Spear-Swerling, Brucker \& Alfano, 2010; and McGeown, 2015).

English student teachers' reading habits had been closely examined based on their reading frequency, their attitudes towards reading, and reading material preferences. The findings and discussion on the three aspects reveal that although generally student teachers' have positive attitude towards reading, they have relatively low reading frequency for both independent study and personal interests. In terms of reading material preferences, fiction genre and online materials are favored by the majority of the student teachers.

\section{Reading Format}

This study also examined whether the student teachers prefer to read in print format or online format.

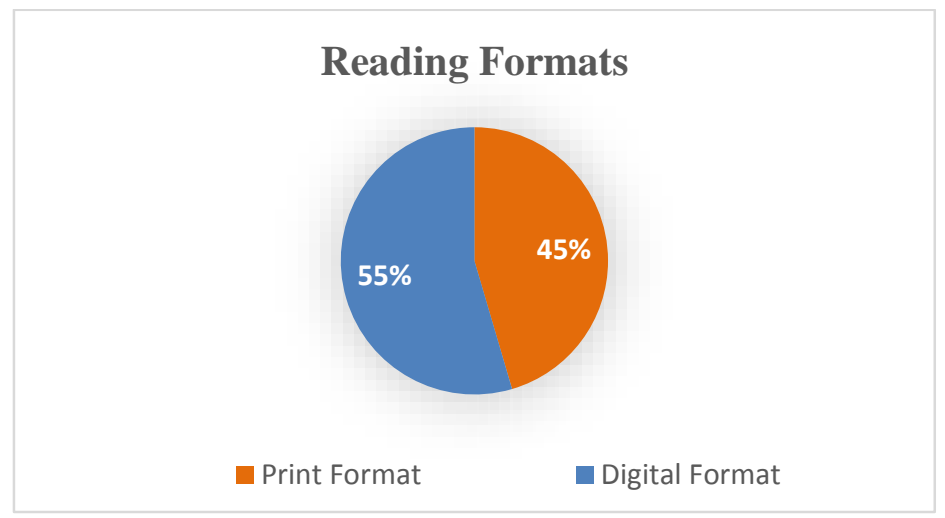

Figure 2. Reading source formats 
Figure 2 shows students reading format preferences. As many as 55\% of student teachers were in favor of the print format. When they were interviewed further, the majority of them said that they choose to read the print format for academic reading. Reading academic textbooks in the print format helps them concentrate better which results in better memorization and comprehension as selfreported by the participants. This is in line with the conclusions of the research conducted by Woody, Daniel, \& Baker (2010) and Parodi et al. (2019). Despite the proliferation of digital technologies and internet access as well as student teachers' high screen time, most of the student teachers chose the print book over the online format for their learning.

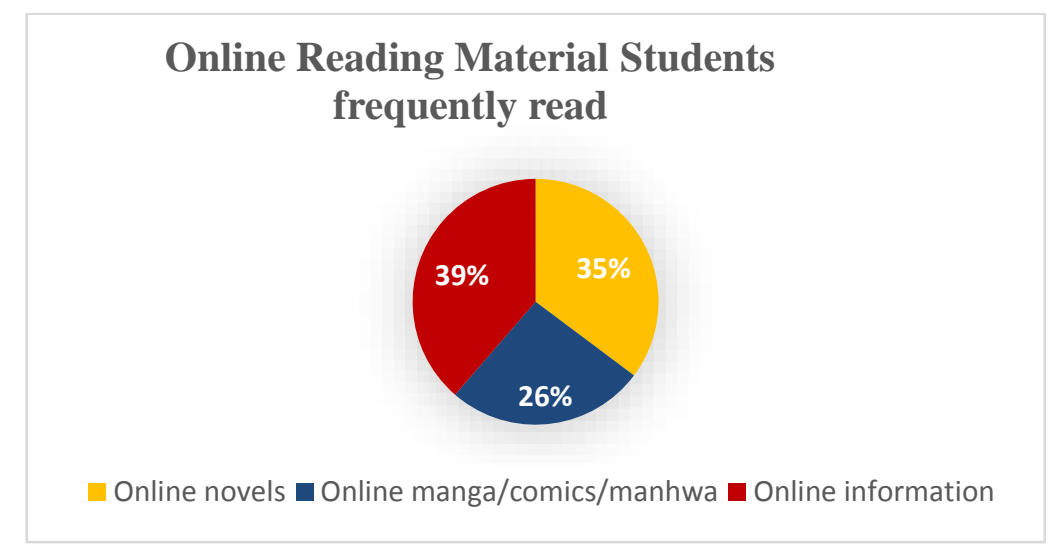

Figure 3. Online Reading Materials

The finding on this section reveals that what the participants most frequently do online related to reading activities is reading online information (39\% of the participants). They said that they surfed the internet to look for information related to news, fashion, entertainment, movie review, book review, gadget review, travelling review, food review, and other information. Then, $35 \%$ of the participants spend their time to read online novels from several online platforms that provide novels/ fiction books for free. Around $26 \%$ of them said that they also use online platforms to read manga/ manhwa/ comic books. It shows that when it comes to read for pleasure or for their personal interest, students mostly do it online. Meanwhile, they prefer to read their course textbooks in print format.

\section{Language Preferences}

Table 4. Language Preferences based on reading materials

\begin{tabular}{|l|c|c|}
\hline \multirow{2}{*}{ Reading Material } & \multicolumn{2}{|c|}{ Language Preferences } \\
\cline { 2 - 3 } & Indonesian & English \\
\hline Academic Text & $53 \%$ & $47 \%$ \\
\hline $\begin{array}{l}\text { Fiction and personal interest } \\
\text { Books }\end{array}$ & $68 \%$ & $32 \%$ \\
\hline
\end{tabular}

Table 4 shows that most of the students are in favor to read in their first language (Indonesian) instead of reading in the foreign language they are currently learning (English). In both academic reading and reading for pleasure, the English student teachers prefer to read in Indonesian. More than half of the participants 
(53\%) chose to read in Indonesian when they read for academic purposes even though they are students of English Language Teaching Department. The same pattern occurs in reading for pleasure. As many as $68 \%$ of participants prefer to read fiction and books of their own choice in Indonesian. This findings suggest that more than half of the English student teachers seem to be reluctant to read in English. During the interview, one of the participants said that she struggled when reading in English. She told us that she had to deal with unfamiliar words, terms, eloquent sentence structures and it took her a long time to understand what she read. Therefore, she thought that reading in English took a lot of energy and was exhausting. The data from both the questionnaire and interviews regarding this section suggest a possible indication of foreign language reading anxiety.

Due to its private and individual nature, reading -especially independent reading- is less susceptible to anxiety effects compared to writing and speaking. However, research shows that foreign language learners also display reading anxiety at certain level (Saito, Garza, \& Horwitz, 1999; sellers, 2000; and Ghonsooly \& Elahi, 2010). The anxiety in foreign language reading might come from unfamiliar phonological, syntactical, and lexical system as well as unfamiliar cultural material. This confirmed what we found out about the pattern in our participants' behavior in reading English texts. Furthermore, the unfamiliar cultural content might be responsible, in part, for why the participants are uncomfortable with reading fiction, which involves substantial cultural items and concepts of the target language (English). English student teachers displaying reluctance to read in English is quite unfortunate because as language learners, reading in the learned language can be one of the most effective ways to develop proficiency in the target language.

\section{CONCLUSION}

This study has shown the reading habits and preferences of a group of English student teachers in Indonesia. The reading habits were predicted from three aspects, i.e. attitudes towards reading, reading frequency, and reading materials. Most of the English student teachers displayed positive attitudes towards reading with fiction books and online materials as the most preferred reading materials. However, most of the student teachers do not dedicate much of their time to independent reading for both academic and pleasure purposes. The participants also displayed reluctance and anxiety towards foreign language reading. They prefer to read in their first language (Indonesian) both for pleasure and for academic purposes.

The pedagogical implication that can be drawn from all these findings is that language teachers/educators and institutions providing English language teachers' training should recognize the importance of reading in general as well as reading in the target language. Language teachers or lecturers should be able to help their students cope with foreign language reading anxiety by creating a learning environment which is less stressful. They should also provide reading motivations by sparking students' interest. This can be done when teachers employ various reading activities. They should also carefully select reading materials that are suitable for students' level and most importantly, they should select reading materials that appeal students' interest. Teachers' training institutions also plays an 
important role. Institutions should provide an environment which fosters students' reading habits by designing reading programs, forming reading clubs, or setting up libraries and comfortable reading areas. Ultimately, it is expected of the institutions to generate a graduate who is a well rounded teacher candidate and at the same time an avid reader.

The findings of this study suggest several issues for further research. Further research can fruitfully explore issues related to first or foreign language reading anxiety. The complexity of factors affecting reading anxiety needs to be disentangled. By identifying the factors causing students to feel anxious about reading could provide some leads for instructional strategies adjustments for better reading. Another issue that could be explored is factors contributing to development of what is perceived to be a good reading habit and I believe that intrinsic reading motivation is the most salient.

\section{REFERENCES}

Anderson, R. C., \& Nagy, W. E. (1993). The vocabulary conundrum. Center for the Study of Reading Technical Report; no. 570.

Applegate, A. J., Applegate, M. D., Mercantini, M. A., McGeehan, C. M., Cobb, J. B., DeBoy, J. R., \& Lewinski, K. E. (2014). The Peter effect revisited: Reading habits and attitudes of college students. Literacy Research and Instruction, 53(3), 188-204.

Channuan, P., \& Wasanasomsithi, P. (2012). Promoting learner autonomy through an extensive reading program among second year undergraduate students of Naresuan University. E-Journal for Researching Teachers, 5, 1-23.

Commeyras, M., Bisplinghoff, B. S., \& Olson, J. (2003). Teachers as readers. Perspectives on the Importance of Reading in Teachers' Classrooms and Lives.

Cox, K. E., \& Guthrie, J. T. (2001). Motivational and cognitive contributions to students' amount of reading. Contemporary educational psychology, 26(1), 116-131.

Cunningham, A. E. (2005). Vocabulary growth through independent reading and reading aloud to children. Teaching and learning vocabulary: Bringing research to practice, 45-68.

Gardner, D. (2004). Vocabulary input through extensive reading: A comparison of words found in children's narrative and expository reading materials. Applied Linguistics, 25(1), 1-37.

Ghonsooly, B., \& Elahi, M. (2010). Learners' Self-Efficacy in Reading and Its Relation to Foreign Language Reading Anxiety and Reading Achievement. Journal of English Language Teaching and Learning, 45-67

Guthrie, J. T., Wigfield, A., Metsala, J. L., \& Cox, K. E. (1999). Motivational and cognitive predictors of text comprehension and reading amount. Scientific studies of reading, 3(3), 231-256.

Hafiz, F. M., \& Tudor, I. (1989). Extensive reading and the development of language skills. ELT journal, 43(1), 4-13

Imrie, A. (2007). Autonomy across the English curriculum through extensive reading. Paper presented at the Independent Learning Association 2007 
Japan Conference: Exploring Theory, Enhancing Practice: Autonomy across the Disciplines, Kanda University of International Studies, Japan.

Krashen, S. D. 2009. Principles and Practice in Second Language Acquisition. Oxford: Pergamon Press.

Krashen, S. D. (2011). Free voluntary reading. ABC-CLIO.

Lee, S. Y., \& Krashen, S. D. (1997). Writing apprehension in Chinese as a first language. ITL-International Journal of Applied Linguistics, 115(1), 27-37.

McGeown, S. P., Duncan, L. G., Griffiths, Y. M., \& Stothard, S. E. (2015). Exploring the relationship between adolescent's reading skills, reading motivation and reading habits. Reading and writing, 28(4), 545-569.

McKool, S. S., \& Gespass, S. (2009). Does Johnny's reading teacher love to read? How teachers' personal reading habits affect instructional practices. Literacy Research and Instruction, 48(3), 264-276.

Morrison, T. G., Jacobs, J. S., \& Swinyard, W. R. (1998). Do teachers who read personally use recommended literacy practices in their classrooms?. Literacy Research and

Nathanson, S., Pruslow, J., \& Levitt, R. (2008). The reading habits and literacy attitudes of inservice and prospective teachers: Results of a questionnaire survey. Journal of Teacher Education, 59(4), 313-321.

Nuttall, C. (1996). Teaching reading skills in a foreign language. Heinemann, 361 Hanover Street, Portsmouth, NH 03801-3912.

Ögeyik, M. C., \& Akyay, E. (2009). Investigating reading habits and preferences of student teachers at foreign language departments. The International Journal of Language Society and Culture, 28, 72-78.

Parodi, G., Moreno-de-León, T., Julio, C., \& Burdiles, G. (2019). Google or Gutenberg Generation: Chilean university students' reading habits and reading purposes. Comunicar. Media Education Research Journal, 27(1).

Priajana, N. (2013). Student teachers' reading habits and preferences. Journal on English as a Foreign Language, 3(2), 71-76.

Renandya, W. A., \& Jacobs, G. M. (2002). Extensive reading: Why aren't we all doing it. Methodology in language teaching: An anthology of current practice, 295-302.

Rimensberger, N. (2014). Reading is very important, but...: taking stock of South African student teachers' reading habits. Reading \& Writing-Journal of the Reading Association of South Africa, 5(1), 1-9.

Ríos, S. R., \& Valcárcel, A. M. (2005). Reading: A meaningful way to promote learning English in high school. Profile Issues in TeachersProfessional Development, (6), 59-72.

Saito, Y., Garza, T. J., \& Horwitz, E. K. (1999). Foreign language reading anxiety. The modern language journal, 83(2), 202-218.

Sangkaeo, S. (1999). Reading habit promotion in Asian libraries. 65th IFLA Council and General Council and General Conference, Bangkok, Thailand, Aug.20-28th.

Sellers, V. D. (2000). Anxiety and reading comprehension in Spanish as a foreign language. Foreign Language Annals, 33(5), 512-520.

Shen. L. (2006). Computer Technology and College Students' Reading Habits. Chia-nan annual bulletin, 32, pp. 559-572. 
Snow, D. (2007). From Language Learner to Language Teacher. Teachers of English to Speakers of Other Languages, Inc. 700 South Washington Street Suite 200, Alexandria, VA 22314

Spangler, K. L. (1983). Reading interests vs. reading preferences: using the research. The Reading Teacher, 36(9), 876-878.

Spear-Swerling, L., Brucker, P. O., \& Alfano, M. P. (2010). Relationships between sixth-graders' reading comprehension and two different measures of print exposure. Reading and Writing, 23(1), 73-96.

Summers, K. (2013). Adult reading habits and preferences in relation to gender differences. Reference \& User Services Quarterly, 52(3), 243-249.

Teng, F. (2018). A learner-based approach of applying online reading to improve learner autonomy and lexical knowledge. Revista Española de Lingüística Aplicada/Spanish Journal of Applied Linguistics, 31(1), 94-123.

Takahashi, W., \& Umino, T. (2020). Out-of-Class Extensive Reading in Japanese as a Second Language: Enhancing Learner Autonomy Beyond the Classroom. Electronic Journal of Foreign Language Teaching, 17(1).

Wagner, S. (2002). The reading habits of teams. Journal of Reading Today, Vol.46: 3-4.

Wigfield, A., \& Guthrie, J. T. (1997). Relations of children's motivation for reading to the amount and breadth of their reading. Journal of Educational Psychology, 89, 420 - 432. doi:10.1037/0022-0663.89.3.420

Woody, W. D., Daniel, D. B., \& Baker, C. A. (2010). E-books or textbooks: Students prefer textbooks. Computers \& Education, 55(3), 945-948. 